\title{
Performing Speaking "Ungrammatical” American English: A Kuwaiti Linguistic Phenomenon
}

\author{
Nada A. Algharabali, Hanan A. Taqi* \\ The English Department, College of Basic Education, Ardhiya, Kuwait \\ Email: ^hanan.taqi@gmail.com
}

How to cite this paper: Algharabali, N. A., \& Taqi, H. A. (2018). Performing Speaking "Ungrammatical" American English: A Kuwaiti Linguistic Phenomenon. Open Journal of Modern Linguistics, 8, 242-261. https://doi.org/10.4236/ojml.2018.86021

Received: November 25, 2018

Accepted: December 21, 2018

Published: December 24, 2018

Copyright $\odot 2018$ by authors and Scientific Research Publishing Inc. This work is licensed under the Creative Commons Attribution International License (CC BY 4.0).

http://creativecommons.org/licenses/by/4.0/

\section{(c) (i) Open Access}

\begin{abstract}
Language attitudes have been addressed by many studies, and the importance of accent choice is one of the attitudes investigated, yet scarcely by EFL educationists. The current study investigates the conscious choice of the American accent by Kuwaiti speakers of English as a foreign language and the importance of accent over other language aspects such as grammar, vocabulary and style as perceived by students. 67 female informants from the College of Basic Education, who are to become potential English teachers and speak with an American-like accent, participated in this study. The informants were given a questionnaire, and after obtaining their consent, their speech was recorded during in-class presentations. Some of the informants were interviewed to elaborate further on the importance of acquiring an American accent. The data was analyzed quantitatively through SPSS (mean and frequency) and qualitatively (through general sociolinguistic and phonetic analysis), and it suggests that most participants believe that achieving an American accent is prestigious and "cool" and more important than developing grammatical and lexical skills.
\end{abstract}

\section{Keywords}

Sociolinguistics, Accents, Phonology, English Language, EFL, Kuwait

\section{Introduction}

The well-documented argument proposing that language, "once acquired, control governing the phonetic implementation of phonological representations becomes automatic and is no longer subject to change" (Kingston \& Diehl, 1994) has been attested and contested in numerous studies. Nothing makes research in 
this area of linguistics more valid than the continuous spread of diversified English worldwide. The stronger the desire for learners to acquire prestige speech varieties of English-especially Received Pronunciation and General American-the more attitudes towards "foreign" accents in EFL contexts become a sensitive issue. Unsatisfied with their foreign accents in spoken English, learners will often do anything they can to emulate a British or American native accent.

Although there is a growing body of literature that addresses language attitude studies, a prevailing limitation lies in representing EFL contexts where issues involving attitudes towards native accents versus foreign accents are brought to the surface in new light. This paucity is especially tangible in EFL contexts existing in the Arab world. And more so in the Gulf region, where relatively little is known about the relationship between English accents usage and identity construction. For this reason, the present paper sheds light over a quantitative and qualitative investigation on the role that native American accent usage plays in an academic EFL context. We examine language attitudes and language choices from an identity construction perspective by eliciting the students' views using a multi-faceted data collection framework. This framework consists of a qualitative and quantitative questionnaire (created based on a pilot investigation conducted in English conversation classes), recorded excerpts from classroom aural presentations, and face-to-face interviews involving a small selection of students. The study starts with a clear review of related literature. This will be followed by the methodology and results. And finally, the discussion will draw on both the results and literature to reach several beneficial conclusions that may prove useful in the EFL field.

\section{Literature Review}

Social discrimination against foreign accents is an age-old issue encountered by many speakers of English around the world. It is of such importance to learners that they endure many hardships in order to overcome the interference of sound patterns from their original language (L1). This is especially common when English (L2) is learned at a late linguistic developmental stage (Beebe, 1988; Seliger, 1988).

Some European accents are deemed favorable. For example, a person with a French accent is sometimes perceived as someone who is well-educated, whereas a speaker with an American accent is in certain settings assumed to be rich (Erard, 2016). Other eastern accents, such as that of a Middle Eastern speaker could conjure up negative stereotypes of an extremist or "just another refugee" (Niedt, 2011). The more negative language attitudes and judgmental stereotypes spread through media, the more learners strive to prevent phonological, syntactic and even idiomatic anomalies from seeping into their spoken English (see Gluszek \& Dovidio, 2010; Derwing, 2003; Fuertes, Gottdiener, Martian, Gillbert, \& Giles, 2012).

A great deal of linguistic research has been done on numerous facets of foreign accented speech in English. And since many scholars see this issue as the main cause of miscommunication, a lot of the existing research revolves around 
intelligibility and comprehensibility of pronunciation (Derwing, Munro, \& Wiebe, 1997, 1998; Couper, 2003; Derwing \& Rositer, 2003; Derwing \& Munro, 2009). Research in this area mostly originates from the widely accepted principle that adult $2^{\text {nd }} /$ foreign language speakers (with some exceptions) have a foreign accent in their speech because authentic pronunciation becomes biologically difficult after a certain age (see Lenneberg, 1967; Seliger, 1988; Scovel, 1988; Flege et al., 1995).

Other studies that adopt notions of learners achieving native-like pronunciation of L2 in spite of a late start, offer opposing arguments to the critical period of L2 acquisition (see Ioup, 1995). For example, a study by Bongaerts et al. (1997) looked at the pronunciation of British English by advanced native Dutch learners who achieved native-like pronunciation in spite of a late start, and were mostly rated as native speakers by native English judges. A similar study conducted on Norwegian learners of English by Rindal (2010) sheds light over learners' perceptions of British English as an accent that is harder to learn, whereas American English as being more prevalent and therefore more dominant among participants.

Research on accents also involves learners' choices of the English language variety that they wish to use, regardless to the variety being used by their educational institution or teachers. A study by Pettersson (2008) presented results showing Swedish secondary school students used a mix of British and American English accents when speaking English despite being taught by teachers who spoke with a British accent. Interestingly, she also pointed out that students often spoke American or imitated an American accent as a direct influence from US television shows and movies.

In fact, American movies, songs, sitcoms and YouTubers continue to provide the greater part of real American English samples throughout the lives of many learners of English worldwide Carvalho (2004). Carvalho argues that, "The determining factor for use of television as a linguistic model to be adopted, is the speaker's negative attitude toward their native dialect and their desire to change it" (2004: p. 142). Although, it has to be said that, many other sociolinguists seem to doubt the relationship between the television and the audience's linguistic behavior (see Trudgill, 1986; Rickford, 1987; and Chambers, 1998). Chambers, for instance, argues that, "there is no evidence for television or other popular media disseminating or influencing sound changes or grammatical innovations" in language usage (1998: p. 126).

Results from anecdotal, experimental and case studies have often presented portrayals of attitudes from speakers and listeners on native accents as prestigious, as opposed to non-native accents as conveying negative stereotypes (Gluszek \& Dovidio, 2010). In addition, extensive research attention has been given to the use of native accents in spoken English in relation to social identity and group membership (Crocker et al., 1998; Côté \& Clément, 1994).

Increasing globalization and intercultural communication often imply that at- 
titudes and beliefs of people who come to live and work in English speaking countries become even more pertinent. Accented-English speakers keenly seek accent reduction tuition in order to conceal their foreignness (Lippi-Green, 2012), in the hope that this would increase job opportunities. Mastering a native accent in this case therefore not only becomes competitive but also increases one's confidence (Gluszek \& Dovidio, 2010).

Much of the linguistic literature landscape surrounding native versus non-native spoken English links increased proficiency in pronunciation with an increase in syntactic and semantic competence (Cook, 1999; Derwing \& Munro, 1997); however the opposite is not necessarily true. In other words, it is unlikely that a learner, who has near-native pronunciation proficiency, would simultaneously demonstrate a lack of grammatical or syntactic competence. And even if there are exceptions to this linguistic pattern of performance, they are not very common and have, as far as we know, received minimal attention by researchers.

This has therefore prompted our keenness to examine the EFL situation in the English Department of the College of Basic education in Kuwait where we also currently teach. After several years of teaching English oral skills (English conversation), it occurred to us that there are three reoccurring linguistic patterns in the speech of the students we teach, notably:

- Some students spoke English with an American accent, but would simultaneously make many structural errors.

- Some students spoke American English while hardly making any structural errors.

- And finally, other students spoke heavily (Arabic) accented English and made almost no structural errors.

Interestingly, most of these students have merely been exposed to a very intermediate level of English commonly taught in public governmental schools. The research questions that we hope to address after examining the collected data are:

1) Why is there a strong tendency to favor learning and speaking English with an American accent?

2) How do many students learn to speak English with an American accent?

3) What are the common characteristics of an American accent that are prevalent in students' speech in the present study?

4) Why do students prioritize learning to use an American English pronunciation to increasing their grammatical and vocabulary knowledge?

\section{Methodology}

The following section provides details of the sample participants and the design of the research methods used in the present study. Choosing college students as a sample to investigate attitudes towards a particular language variety (American English, in this case) was rather ideal because of the fertile linguistic background associated with this academic context. These students are presently studying a 
4-year bachelor degree program in English language and literature at the English Department of the College of Basic Education (CBE) in Kuwait. More specifically, they are first-year students attending three basic skills English courses: reading, writing and conversation. Additionally, they are female students (due to the fact that CBE is a woman's college), and their average ages range from $19-22$ years. For the purpose of our study, which focuses on aural language choices and attitudes, we have asked two different groups of students from two semesters (i.e. a full academic year 2017-18) who spoke in an American-like accents, whether they are willing to participate in responding to a questionnaire. The questionnaire was supplemented by face-to-face interviews with a small number of students who volunteered to take part in this section of the present investigation.

The questionnaire (see Appendix 1) was designed based on a number of pilot questions that were utilized as group discussion topics during conversation classes from the previous academic year (2016-17). The questionnaire consisted of 14 questions to be answered on a Likert scale. Questions 1 - 4 targeted the students' insights on their English language proficiency and the extent of exposure to this language. Questions 5, 6, 7 and 9 were designed to elicit the students' attitude towards American English, specifically (following the realization that this variety of English is favored among students). Questions 8 and 10 focused on finding out which area of language proficiency tended to be more important to students: structure, pronunciation, and knowledge of vocabulary or style. Questions 11 - 13 aimed to reveal students' perceptions on how well they pronounced English with an American accent, as well as the length of time it took them to acquire this accent. Finally, question 14 was strategically placed at the end of the questionnaire to encourage students to share any tips on how best to acquire an American English accent. 70 questionnaires were given out to students, who opted to take part, but only 67 questionnaires were fully completed and considered, while 3 were eliminated. Although the researchers were hoping for a large number of students considering the total number of students in all the conversation courses is 280; however, there is a limited number of students who speak with an American accent.

Additionally, only 6 students chose to participate in face-to-face interviews. These students opted to take part in the interviews because they wanted to present a narrative in answer to some of the questions from the questionnaire. Individual interviews were carried out after class at each student's convenience by one of the researchers (the first author of the present study), who took down shorthand notes as students were engaged in discussion. Each interview typically lasted around 7 - 10 minutes and mainly revolved around repeating two of the questions that appeared in the questionnaire (questions number 2 and 14, see Appendix 1). The idea behind the interviews was to facilitate elicitations from students and encourage them to add longer discussions they may not have been able to include when answering the questionnaire. The data collected from the questionnaire were entered in SPSS and analyzed to obtain mean, frequency and 
significance, where significance is calculated at $p \leq 0.05$.

Since students' perceptions on how they felt about American English and their level of proficiency in this variety are both important issues, it was necessary for us to determine whether these perceptions corresponded to characteristics in their spoken English in class. Therefore, to find out more about the students' spoken proficiency and existing patterns of speech in the variety of English that they have chosen to use, we decided to record classroom sessions from their conversation course. This was done following the students' consent to having their speech recorded and used as data for the purposes of the present study.

\section{Results}

\subsection{Quantitative Findings}

Most of the students who participated in this study speak in an American-like accent. However, not all of them have a good command of the English language grammatically and syntactically. Hence, it was essential to understand the way the participants view their language ability, and how important acquiring an accent is to them.

The first question (see Appendix 1) enquired about the informants' English accent. $39.2 \%$ of the participants believed that their American accent sounds cool, while $27 \%$ feel that they sound like American native speakers. Two students stated that while they speak with an American accent, traces of a mild Arabic-English accent often infiltrated into their speech, especially when they are nervous. Figure 1 below, depicts the students' views of their American English accent.

When the students were asked how they gained their accent, $46.7 \%$ stated it was from watching movies, and $26.2 \%$ stated it was from listening to songs. Two students believed that their families encouraged their use of an American accent and helped them practice it at home. Other methods of being exposed to the language were gaming, reading books and watching YouTube. Figure 2 below, displays percentages of the importance of the methods used by informants to acquire an American accent.

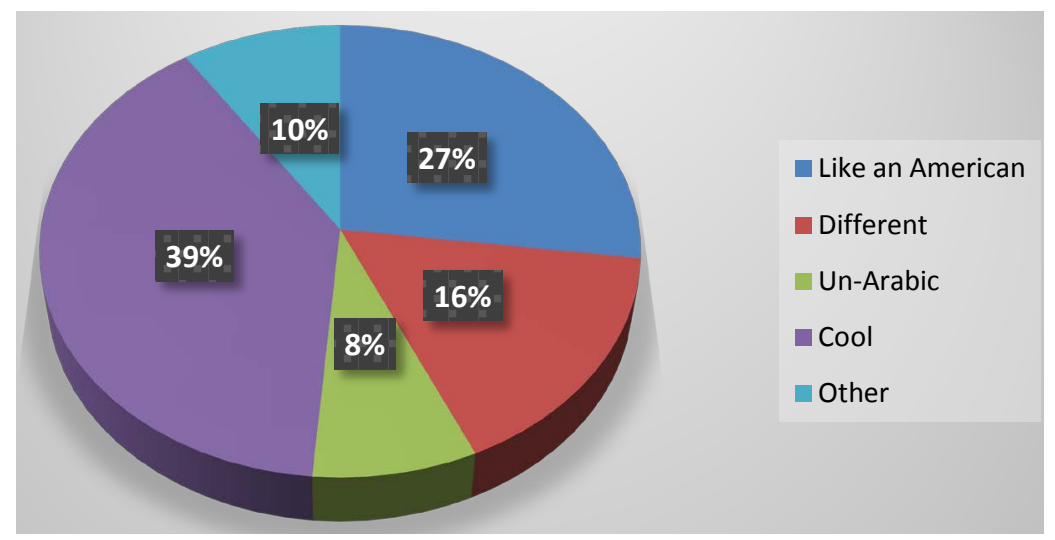

Figure 1. Answers to "how does your accent sound?". 


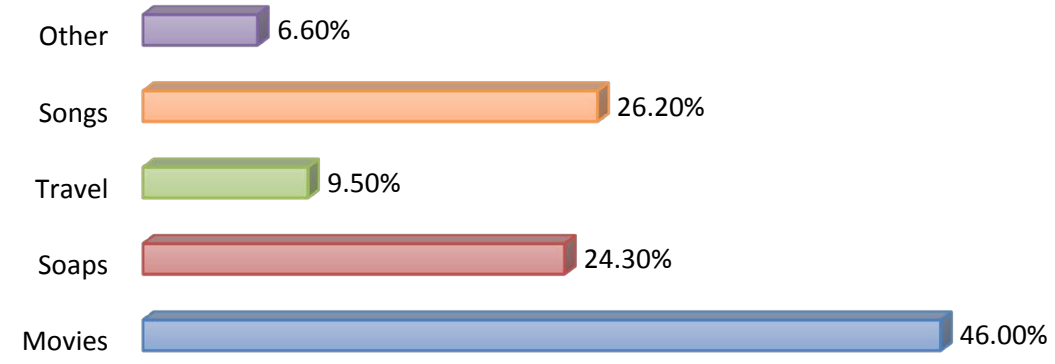

Figure 2. Answers to "how did you gain your American accent?".

The amount of practice required to acquire the American accent being used by informants was investigated next. $49.3 \%$ of the participants stated that they practice for more than one hour daily. Many students practiced once a week, and some stated they had set 4 hours a week to practice. Other students dedicated their time watching at least one series a day of their favorite sitcom in order to be exposed to the accent. In addition, it seems that several students practice whenever they have spare time. This reflects the importance of acquiring an American accent to these students. Yet, most students do not always feel that they put an effort to learn the language (49.3\%). While only $6 \%$ noted they need to put in the required effort when speaking with an American accent, 28.4\% felt it comes naturally to them. As for the rest, which are the majority, they felt it is a process of both effort and natural flow of speech combined.

The use of an American accent is important to $38.8 \%$ of the informants. Many reasons where provided to support this idea. Some students felt that the use of an American accent reflects the amount of effort they put into learning the language. Moreover, many students believed that the use of an American accent is important because it is the accent that is most widely spread. It also reflects professionalism and a status of high education. They added that using the American accent, especially with native speakers, makes the messages presented by speakers clearer and easier to understand. In addition, some students stated that they use the American accent whenever they can to practice the language and perfect it. Nonetheless, $40.3 \%$ of the students believed it is not always important to use an American accent. Many of whom, felt that non-native speakers of English might find it hard to understand. Hence, these students would mostly use the American accent in professional environments, such as in school or in formal interviews. Some students, on the other hand, believed that using an American accent is not important (20.9\%). They proposed that in communication, a lot of importance should be placed on delivering the message and communicating affectively regardless of the accent.

The majority of the participants reflected their pride in the use of the American accent (56.7\%). They mainly found their ability to be unique because it distinguishes them as "smart". These students were proud of themselves because they are aware that other students find it very difficult to acquire an American accent, thus, their ability to speak with an American accent is unique. Five students stated that they feel proud when they speak with an American accent be- 
cause it is an international language, and therefore used worldwide. The students used the words "clear", "right accent" and "language of communication" when describing the accent. Some students felt that they could not be proud of using the American accent, especially with people who find it difficult to understand. Four students stated that they are not always proud of their American accent, because they find that not everybody appreciates it and it might seem like they are showing off.

With whom do informants use their American accent? Most participants stated that they use their American accent with everyone, especially with their teachers. The reason for this choice is the belief that the more they use the accent, the better command of it they will gain. However, some students prefer not to use it with their families and friends because they are shy, and believe it is not always acceptable. Figure 3 below, reflects the affect of the recipient on the choice of accent by the speaker.

The reason for using the American accent differs between informants, yet many informants use the American accent because it is the most common worldwide, thus they could be understood easily. Some students stated that although they feel that the American accent is cool, they believe it is not acceptable or understood by everyone. One student stated that she learned to speak with an American accent because when spoken in appropriate situations, it sounds clear and polite. Figure 4 below, reflects the reasons participants stated they choose to speak with an American accent.

The informants were asked to choose the most important aspect of language, and then to arrange certain aspects in terms of importance. Most students believed that being understood is the most important feature of spoken language (33.6\%), while being "cool" was the least important. When arranging the language aspects, vocabulary seemed to be the most important feature, coming first $37.3 \%$ of the time. Grammar, however, was listed as the least important feature of language scoring $52 \%$ in last place. Figure 5 below, reflects the important aspects of a language according to the informants.

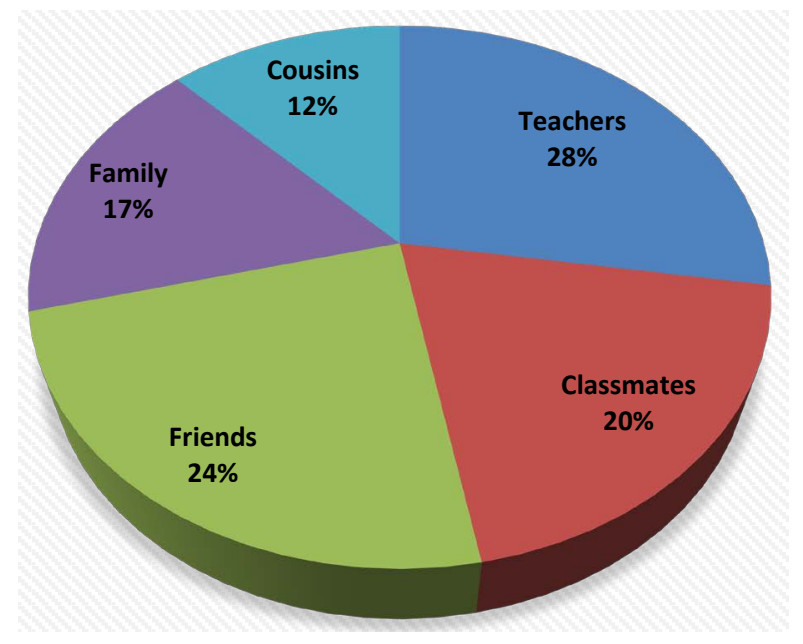

Figure 3. Answers to "who do you use the accent with?". 


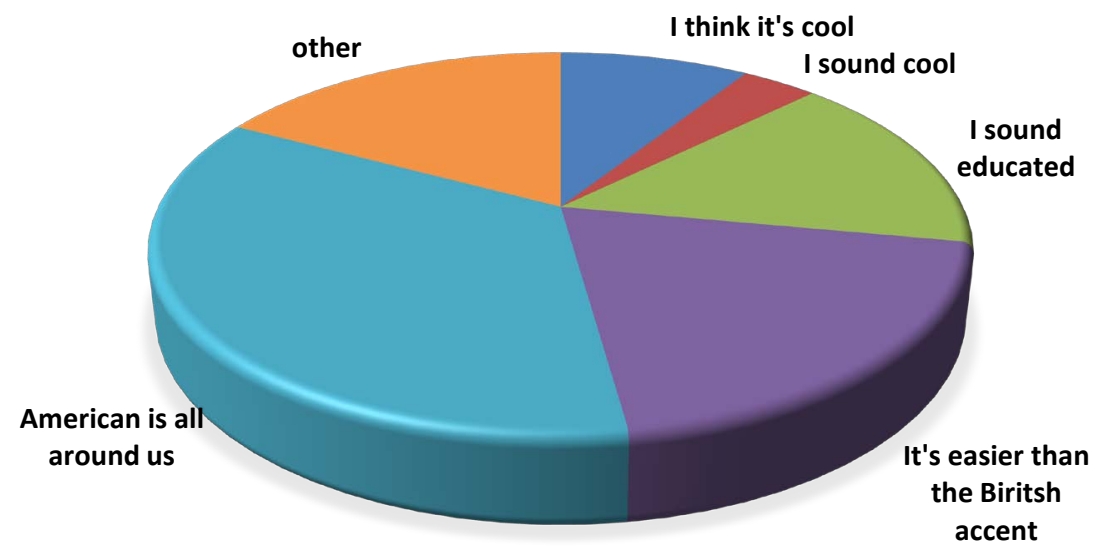

Figure 4. Answers to "why do you choose to speak in an American accent".

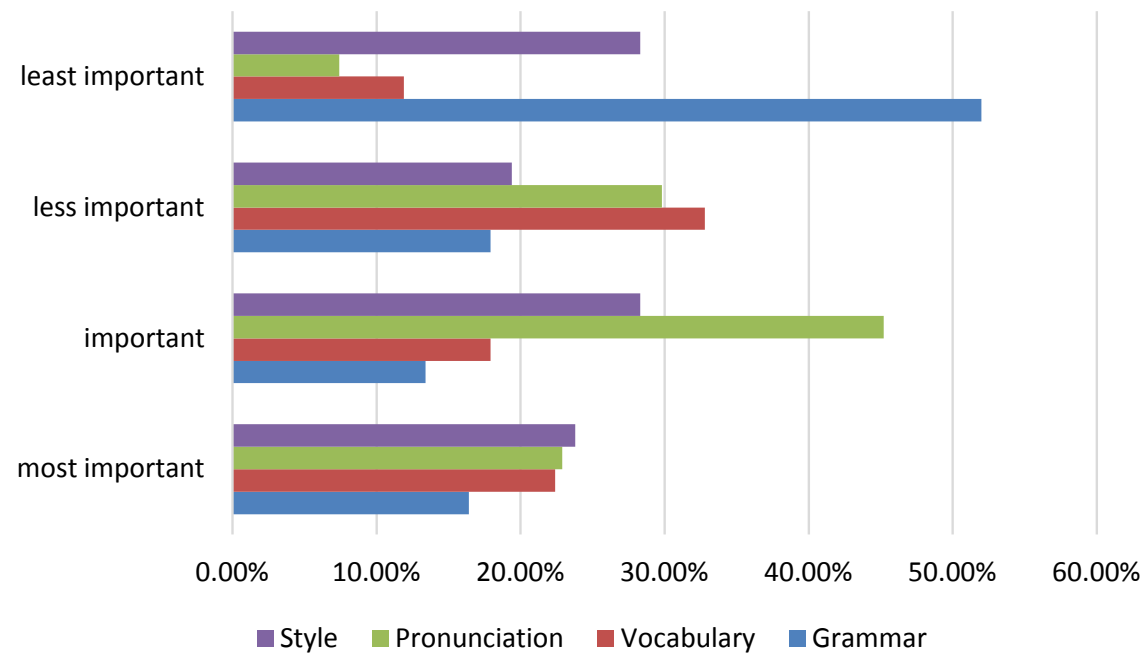

Figure 5. Arranging language aspects according to importance.

Most students stated that they have learned to speak with an American accent gradually over the years $(68.2 \%), 15.2 \%$ revealed that they learned to speak with an American accent in two years, while $16.7 \%$ believe they learned to speak the accent in only one year. Most students rated themselves highly in terms of language proficiency and command of the American accent, reflecting high confidence in their abilities. Figure 6 below, depicts the students' evaluation of their language proficiency and command of the American accent.

As can be seen in Figure 6, the majority of students, who use American-accent features in their speech, grade themselves highly in term of language proficiency, clearly linking proficiency with native accents.

\subsection{Qualitative Findings}

\subsubsection{Open-Ended Questions}

As mentioned earlier (see Methodology 3.0), questions 5 and 6 were specifically designed to encourage students to share perceptions and attitudes towards the American accent as a variety of English (see Appendix 1). Question 5 focused 


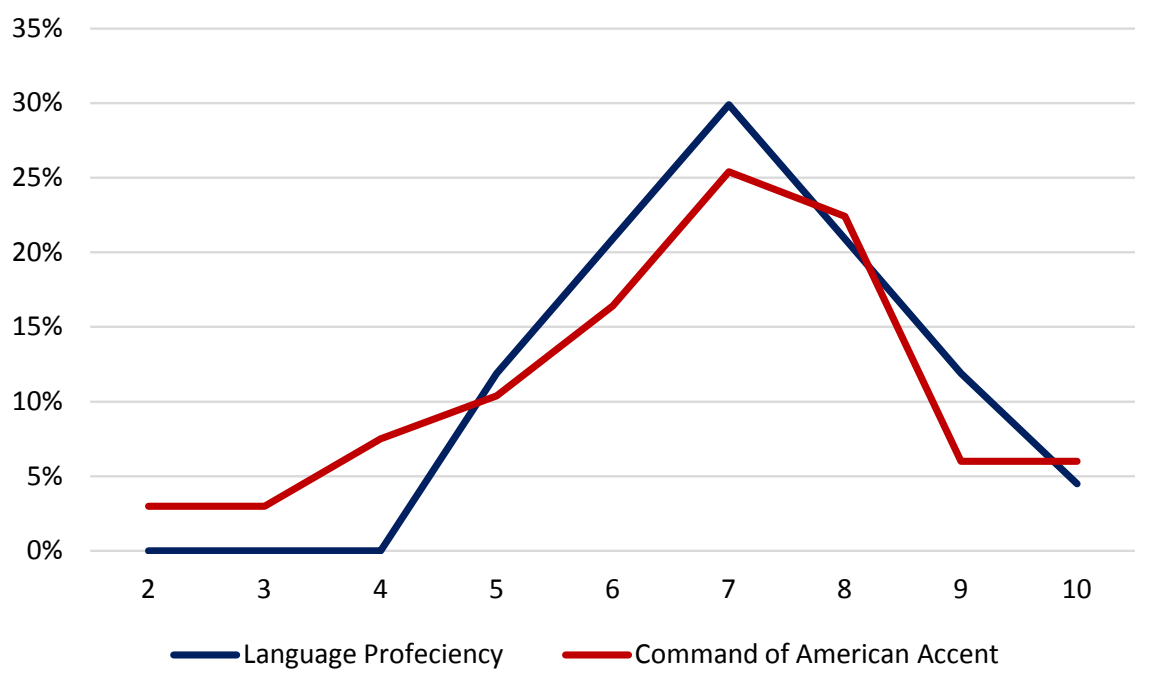

Figure 6. Rating language proficiency and American accent command on a scale of 1 10,10 being perfect.

on the importance of speaking with an American accent, while question 6 focused on whether students felt speaking American English is a privilege.

In response to question 5, many of the students believed that speaking English with an American accent is important because it is more popular and common worldwide. The interesting part in their comments was the various adjectives used to explain the importance of American English: it sounds "smart, cool, easy to understand, better and less complicated than British English, more polite, clear, and educated". However, a number of students expressed their disagreement to the idea that using American English in speech is important. They seemed to gravitate instead more towards comprehensibility with the majority of the comments expressed the following: "as long as people understood what I'm saying" and "if my message is clear... then speaking with an American accent is not really necessary".

As for question 6, many students did not experience a sense of pride in being able to speak with an American accent and strongly expressed views about being proud of who they are without a need to "imitate Americans". They placed more importance on "speaking with confidence" and "sounding spontaneous" even if it meant, "using a mild Arab (foreign) accent". Some of the other students, on the other hand, felt proud that they are able to speak English and stated that they feel "different than the rest" and even "better than the rest". The "rest" being the other students who they perceive as less fortunate because they speak English with a strong Arabic accent.

The final question (Number 14) is an open-ended question which allows students to express themselves freely, as well as provide general tips to other students on how best to acquire an American accent. Most students tended to agree that watching movies, sitcoms and YouTube are the best and quickest way toward learning to speak like American native speakers. But equally important to them seemed to be practicing reading regularly. Some students mentioned the 
importance of not simply relying on college English classes (due to limited language exposure), but also supplementing that by going to English language training centers. While others have given detailed steps on how to acquire an American accent through regularly watching American movies. The students seemed divided: some against watching movies with Arabic subtitles, and others for using subtitles. While a few students actually provided practical detailed advice on how to learn English by watching movies:

"When watching American movies, start with Arabic subtitles, then move onto English subtitles, and finally don't use subtitles, once you feel competent enough to understand a movie without depending on subtitles."

\subsubsection{Interviews}

Interviews were conducted with a small sample of students, who felt they needed to add more insights and share individual experiences about their English language proficiency or their achievement in speaking English with an American accent. Two of these experiences caught our attention: one of which (student A) who forced herself to acquire an American accent under dire circumstances, while another (student B) had chosen a very creative way to teach herself how to speak with an American accent.

Student A was in $11^{\text {th }}$ grade when she was ostracized by her English teacher (an Arab national) for being poor at English; to the extent where the student was regularly punished in class and eventually failed the course. The student was equally punished by her parents for failing and as a result, she reacted desperately by making a pact with herself to spend the whole summer vacation of that year (about three months) teaching herself English-mainly through watching movies. So intensive was her voluntary self-exposure to the English language that she succeeded in acquiring it to a degree where she passed both her high school and college English courses with ease.

The experience of student $\mathrm{B}$, however, is not as intense, but is another example of self-taught American-accented English. Student B developed a strong interest in English at a young age (9 years) and ventured into a journey of extensively reading English books while also supplementing that by watching American movies and sitcoms. She eventually achieved a high level of competence in English and felt confident enough to initiate online friendships with native American and Canadian users. These users later became her close friends and she practiced speaking English to them almost daily for long periods of time.

It is worth noting that, based on our interviews with these two students, among others, we observed that student B seemed more grammatically competent when conversing in English and displayed good knowledge of vocabulary. This in turn, projected spontaneity and confidence on her part. Student A's speech, in comparison, lacked variety in vocabulary usage (e.g. excessive use of "cool" and "like" as a filler), and seemed less spontaneous, more hesitant. Also, she generally tended to use slang (e.g. "gonna"), and idiomatic American English (e.g. "I love speaking English. It's a piece of cake for me"). 


\subsubsection{Features of Speech Patterns from Recorded Excerpts}

The American English accent has several distinctive features that are the target of people who want to learn the accent. One of these features is the lack of vowel rounding / $/ \mathrm{p}$ known as the father-bother merger, where words like "cot" and "caught" would be realized as [kat]. Another common feature of the American accent is the realization of /t/ and /d/ as an alveolar tap [r] when in medial position, such as the production of the word "city" as [srri:]. In other cases, when $/ \mathrm{r}$ / is in the beginning (or towards the beginning) or end of a word, it would be realized as /.I/ such as in the word /.xart/ "write" which depends on pulling the tongue slightly backwards, fattening it and raising it in the middle touching the sides and bottom of the upper teeth. The tip of the tongue goes down touching nothing, and the lips round. Coalescence is also a feature known in American English, whereby two sounds join together because of speaking fast to produce a new sound. In this feature, the alveolar sounds $/ \mathrm{t} /$ and $/ \mathrm{d} /$ are followed by $/ \mathrm{r} /$ or $/ \mathrm{j} /$, when these sounds get in contact, the affricates $\left[\mathrm{d}_{3}\right]$ and $[\mathrm{t}]$ are produced, such as in words like "dry" [dgrar] and "try" [t rar . An additional way to distinguish the American accent is through rhoticity. The vowel contact with $/ r /$ in most American accents would produce a rhotic [3] and [ə] , as found in words like [bзrd] "bird" and [ti:tðo] "teacher". Finally, most American accents are known to slightly velarize /1/ into a dark tone [1], such as in words like "clear" [kti:r] and "apple" [æpəł] (see Excerpt 1).

The distinctive phonological features of the American accent are the aim of many non-native speakers of English. Kuwaiti speakers of English usually have the tendency to mix the British accent with the American and with a little L1 affect to produce a unique Kuwaiti English accent. For example, Kuwaiti English is known for its trills. Hence, a Kuwaiti would not realize the word "baker" as American [berkə] or the British [berkə], but instead as [berker], and the American /g.rll/ "grill" would be realized as /gril/. Therefore, when attempting to learn to speak with an American accent, Kuwaitis might add more rhoticity and rounding to the $/ \mathrm{f} /$ making it sound artificial. Also, as $/ \mathrm{d} /$ is considered one of the hardest American sounds to acquire by non-natives, many Kuwaitis would pronounce it more like a /d/ making it impossible to hold, or curl the tongue backwards which sounds a little similar but hollow. When pronouncing a word like "butter", Kuwaitis usually confuse / $/$ / with /d/ making the word sound like $/ \mathrm{b} \Lambda \mathrm{d} \gamma /$ rather than $/ \mathrm{b} \Lambda \mathrm{r} \gamma /$. Another distinctive feature of Kuwaiti English is the absence of the diphthongs /ov/ and /ov/, which result in words such as "know" to be realized as [no]. The Kuwaitis who attempt to speak with an American accent use /ov/ often. Coalescence is not a characteristic found in Kuwaiti Arabic. Therefore, words such as "try" and "dry" would be realized as [trar] and [drar] respectively. These realizations reflect the Arabic alveolar trill $/ \mathrm{r} /$ distinctively. Since Kuwaiti Arabic uses a trill /r/, words like "teacher" and "bird" would be produced as [ti:fer] and [berd]. Attempting to turn the /r/ into a rhotic consonant, causes the sound to be more rhotic than usual in most cases. While the dark / $\mathbf{t} /$ is available in Kuwaiti Arabic, it is not a common sound. In fact, it is 
only used in the word "God" [?ałta]. The Arabic [1] is heavier than the American one. This has caused confusion among those attempting to learn the American accent, as many Kuwaitis use the Arabic darker [ $\mathrm{t}$ ] to represent the American lighter one. The two excerpts below present patterns of speech typically found in students' spoken English. Finally, Kuwaiti Arabic has no /p/ sound (the voiceless, bilabial stop) in its phonetic system, which usually means that learners compensate for it by pronouncing the closest corresponding voiced sound /b/ causing words like "park" and "hop" to be pronounced as [ba:rk] and [hpb] (see Excerpt 2).

These patterns project two categories of students: those who speak Arabic accented English, tend to make relatively few grammatical and syntactic errors and have good vocabulary knowledge, and those who speak English with an American accent and tend to make relatively more errors.

Excerpt 1: (Story telling in English spoken with an American accent)

"She felt there was something wrong with her but didn't figure out what... A couple of month_ later, the results showed up and it turns out that she has a cancer. That news totally sucked!"

Excerpt 2: (Story telling in English spoken with an Arabic accent)

"Unfortu*nately, She felt very apused and unhabby. She knew that she had to be more assertive when interacting with people. Anna was aware that her $\underline{b}$ bast as an orphan would make her feel uncom ${ }^{\star}$ fortable." ( ${ }^{\star}$ misplaced syllable stress)

\section{Discussions}

It is clear from our findings that many of the participants in this study acknowledge the importance of achieving high levels of English language competence, although, some appear "disillusioned" into believing that linguistic competence may satisfactorily be limited to appropriate pronunciation only. Similar to Carrie's (2017) findings in Spain and those of Rindal (2010) in Norway, our results, on the whole, support the notion that learners favor the American accent when speaking English. This observation is not only based on common perceptions that American English is both easier to produce and understand (see Results 4.1), and in turn simpler to acquire (or "pick up" from American media entertainment, as proposed by Carvalho, 2004), but also because it is socially attractive and widespread (Carrie, 2017). Most importantly, our results also suggest that although the students have placed so much significance on achieving good knowledge of vocabulary (see quantitative findings Section 4.1), their efforts tended to focus essentially on choosing and acquiring American pronunciation (see qualitative findings Sections 4.2). It is worth mentioning here that their choice to acquire and communicate with an American accent (among other English accents, such as British or Australian English) reflects the way that social meanings impacts linguistic choices and identity representation. In other words, these students clearly seem to regard American English as a prestige language variety and have chosen to position themselves in close connection with this variety (Bucholtz \& Hall, 2005). 
However, the area in which our findings most clearly diverge from those of other researches is that the participants in the present study, presumably unintentionally, believe that by imitating the pronunciation of native American speakers of English, they are accordingly, highly proficient in English. What appears to have escaped them is that their self-taught initiative, which relies mainly on being exposed to American media entertainment, may be beneficial when it comes to acquiring verbal skills, but fails to help them develop in other areas of language, such as the acquisition of grammar, syntax and vocabulary. In fact, most students found grammar to be the least important language component to be acquired, which accounts for the reason their grammar is not perfected as their accent.

Consequently, our main concern towards the students we teach is that they are unaware of their lack of grammatical competence in English. And while we do bring it to their attention when correcting their structural errors, their reactions are charged with disbelief because of the popular misconception they often use to justify their flawed linguistic behavior: "But I speak very good English!" Therefore, assuming that the argument of the critical period of L2 acquisition, mentioned earlier (see Lenneberg, 1967; Seliger, 1977; Walsh \& Diller, 1979; Scovel, 1988; and Flege, 1995), is untrue in our case, we have to caution that there are other factors to consider here, and not just achieving native speaker pronunciation.

One factor is the ability to successfully "imitate" a particular variety of English pronunciation (the American accent) by self-taught methods. Another factor is prioritizing the acquisition of pronunciation over correct grammatical and syntactic usage as well as lexical development. Fortunately, both factors suggest high motivation and agency on behalf of the learners. Thus, given the rather deficient current EFL situation in Kuwait, such a dedicated and positive initiative by learners to help themselves develop linguistically is (pedagogically) highly appreciated by consciences English teachers. But, it has to be added here, that teachers can also play an important part in redirecting the learners' aural self-taught efforts to enable them to develop an awareness of other equally important areas of English language acquisition.

Reading, for example is a valuable source of input, which encompasses a more holistic approach toward language exposure. Interestingly, audiobooks are a practical solution to today's millennial learners, who blame reading of being a boring activity. At the same time, audiobooks also expose learners to pronunciation and a chance to hear different varieties of spoken English, albeit by listening to better language levels then those found in media entertainment. Figure 7 below, draws a comparison between two sources of learner language exposure: reading and media.

Additionally, the actual task of reading a book enables learners to strengthen their spelling (an equally challenging area of English language acquisition) and reinforces correct grammatical and syntactic formations of English sentences. 


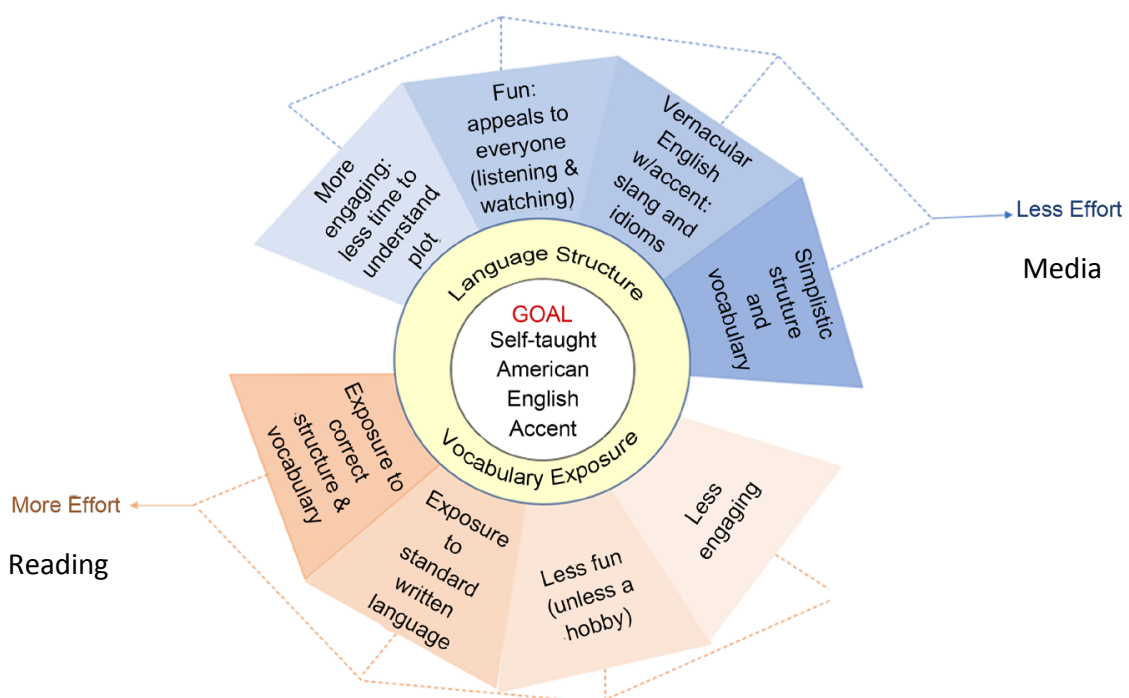

Figure 7. Self-taught methods to acquire an American accent according to participants.

Reading, also simultaneously teaches learners new vocabulary and engages more senses, such as what sentences look like and what they mean (see Kyongho \& Nation, 1989; and McCormick, 1994). Reading for leisure should inevitably involve interesting books with easy accessible language to prevent learners from getting bored of reading.

\section{Conclusion}

In conclusion, the present study argues that it appears highly inconceivable for learners to become linguistically proficient in most areas of the English language, including sounding like near-native Americans, simply by being exposed to American media entertainment for substantial periods of time, daily. However, since the phonetic skills of "imitating" an American accent seem to be possible for the students in the present study (despite late language acquisition) as well as appealing to them (because an American accent is "cool"), then teachers should strongly encourage this initiative further. Moreover, teachers could find ways to offer a guided self-taught program for acquiring English. This suggests areas of research that are well worth developing for future directions in teaching English to Kuwaiti learners.

\section{Conflicts of Interest}

The authors declare no conflicts of interest regarding the publication of this paper.

\section{References}

Beebe, L. M. (1988). Issues in Second Language Acquisition: Multiple Perspectives. Boston: Newbury House.

Bongaerts, T., van Summeren, C., Planken, B., \& Schils, E. (1997). Age and Ultimate Attainment in the Pronunciation of a Foreign Language. Studies in Second Language 
Acquisition, 19, 447-465. https://doi.org/10.1017/S0272263197004026

Bucholtz, M., \& Hall, K. (2005). Identity and Interaction: A Sociocultural Linguistic Approach. Discourse Studies, 7, 585-614. https://doi.org/10.1177/1461445605054407

Carrie, E. (2017). “British Is Professional, American Is Urban”: Attitudes towards English Reference Accents in Spain. International Journal of Applied Linguistics, 27, 427-447. https://doi.org/10.1111/ijal.12139

Carvalho, A. M. (2004). I Speak Like the Guys on TV: Palatalization and the Urbanization of Uruguayan Portuguese. Language Variation and Change, 16, 127-151. https://doi.org/10.1017/S0954394504162030

Chambers, J. (1998). TV Makes People Sound the Same. In L. Bauer, \& P. Trudgill (Eds.), Language Myths (pp. 123-131). New York: Penguin Books.

Cook, V. (1999). Going beyond the Native Speaker in Language Teaching. TESOL Quarterly, 33, 185-209. https://doi.org/10.2307/3587717

Côté, P., \& Clement, R. (1994). Language Attitudes: An Interactive Situated Approach. Language \& Communication, 14, 237-251. https://doi.org/10.1016/0271-5309(94)90002-7

Couper, G. (2003). The Value of an Explicit Pronunciation Syllabus in ESOL Teaching. Prospect, 18, 53-70.

Crocker, J., Major, B., \& Steel, C. (1998). Social Stigma. In D. T. Gilbert, S. T. Fiske, \& Lindzey, G. (Eds.), The Handbook of Social Psychology (4th ed., Vol. 2, pp. 504-553). New York: Academic Press.

Derwing, T. (2003). What Do ESL Students Say about Their Accents? Canadian Modern Language Review, 59, 547-567. https://doi.org/10.3138/cmlr.59.4.547

Derwing, T. M., \& Munro, M. J. (1997). Accent, Intelligibility, and Comprehensibility: Evidence from Four L1s. Studies in Second Language Acquisition, 19, 1-16. https://doi.org/10.1017/S0272263197001010

Derwing, T. M., \& Rossiter, M. J. (2003). The Effects of Pronunciation Instruction on the Accuracy, Fluency, and Complexity of L2 Accented Speech. Applied Language Learning, 13, 1-17.

Derwing, T. M., Munro, M. J., \& Wiebe, G. (1997). Pronunciation Instruction for Fossilized Learners. Can It Help? Applied Language Learning, 8, 217-35.

Derwing, T. M., Munro, M. J., \& Wiebe, G. (1998). Evidence in Favor of a Broad Framework for Pronunciation Instruction. Language Learning, 48, 393-410. https://doi.org/10.1111/0023-8333.00047

Derwing, T., \& Munro, M. (2009). Putting Accent in Its Place: Rethinking Obstacles to Communication. Language Teaching, 42, 476-490. https://doi.org/10.1017/S026144480800551X

Erard, M. (2016). The Reason You Discriminate against Foreign Accents Starts with What They Do to Your Brain. Nijmegen: Max Planck Institute of Psycholinguistics. http://www.google.com/amp/s/qz.com/624335

Flege, J. E., Munro, M. J., \& MacKay, I. R. (1995). Factors Affecting Strength of Perceived Foreign Accent in a Second Language. The Journal of the Acoustical Society of America, 97, 3125-3134. https://doi.org/10.1121/1.413041

Fuertes, J. N., Gottdiener, W. H., Martin, H., Gilbert, T. C., \& Giles, H. (2012). A Meta-Analysis of the Effects of Speakers' Accents on Interpersonal Evaluations. European Journal of Social Psychology, 42, 120-133. https://doi.org/10.1002/ejsp.862

Gluszek, A., \& Dovidio, J. F. (2010). The Way They Speak: A Social Psychological Pers- 
pective on the Stigma of Nonnative Accents in Communication. Personality and Social Psychology Review, 14, 214-237. https://doi.org/10.1177/1088868309359288

Ioup, G. (1995). Evaluating the Need for Input Enhancement in Post-Critical Period Language Acquisition. In The Age Factor in Second Language Acquisition (pp. 95-123). Clevedon: Multilingual Matters.

Kingston, J., \& Diehl, R. L. (1994). Phonetic Knowledge. Language, 70, 419-454. https://doi.org/10.1353/lan.1994.0023

Kyongho, H., \& Nation, P. (1989). Reducing the Vocabulary Load and Encouraging Vocabulary Learning through Reading Newspapers. Reading in a Foreign Language, 6, 323-335.

Lenneberg, E. H. (1967). The Biological Foundations of Language. Hospital Practice, 2, 59-67. https://doi.org/10.1080/21548331.1967.11707799

Lippi-Green, R. (2012). English with an Accent: Language, Ideology and Discrimination in the United States. New York: Routledge. https://doi.org/10.4324/9780203348802

McCormick, K. (1994). The Culture of Reading and the Teaching of English. Manchester: Manchester University Press.

Niedt, G. (2011). Arabic Accent and Perception in the USA. Doctoral Dissertation, Washington DC: Georgetown University.

Pettersson, J. (2008). British, American or Mid-Atlantic English: What Accent Do Swedish Learners Use and Where Do They Get Their Influences from? Unpublished MA Dissertation, Karlstad: Karlstads Universitet.

Rickford, J. (1987). Language Contact, Variation and Diffusion: Microlevel Community Perspectives (pp. 25-44). Georgetown University Round Table on Languages and Linguistics.

Rindal, U. (2010). Constructing Identity with L2: Pronunciation and Attitudes among Norwegian Learners of English 1. Journal of Sociolinguistics, 14, 240-261. https://doi.org/10.1111/j.1467-9841.2010.00442.x

Scovel, T. (1988). A Time to Speak: A Psycholinguistic Inquiry into the Critical Period for Human Speech. New York: Newbury House Publishers.

Seliger, H. (1977). Does Practice Make Perfect? A Study of Interaction Patterns and L2 Competence. Language Learning, 27, 264-278.

https://doi.org/10.1111/j.1467-1770.1977.tb00122.x

Seliger, H. (1988). Psycholinguistic Issues in Second Language Acquisition. Issues in Second Language Acquisition: Multiple Perspectives, 1, 988.

Trudgill, P. (1986). Dialects in Contact. Blackwell.

Walsh, T. M., \& Diller, K. C. (1979). Neurolinguistic Considerations on the Optimum Age for Second Language Learning. In Annual Meeting of the Berkeley Linguistics Society (Vol. 5, pp. 510-524). Berkeley's Linguistic Society, Online.

https://doi.org/10.3765/bls.v5i0.2157 


\section{Appendix 1}

\section{QUESTIONNAIRE}

As your teachers of English, we need not only investigate the needs of the Ministry of Education, but also your needs and preferences as our students. Which of the skills of English should we emphasize? What would you like to learn? How would you like to learn? By answering this questionnaire, you will assist us in designing better course martial that is not borrowed from textbooks, but tailored to fit your needs. Please answer the following questions. You can choose more than one answer if you like.

1) How do you think you sound when speaking English with an American accent?

- Like an American

- Different from the rest of the students

- Un-Arabic

- Cool

- Other

2) How did you learn how to speak English with an American accent?

- American movies

- American soap operas (e.g. "Friends")

- Travelling

- American songs

- Other

3) How much American soap operas and movies do you watch?

- Daily for 1 hour approx.

- Daily more than 1 hour

- Other

4) Do you have to make an effort to speak with an American accent or does it come naturally?

- I make an effort

- It comes naturally

- Sometimes both

- I don't know

5) Do you think speaking with an American accent is important? Why?

- Yes

- Sometimes

- No

- Why?

6) Are you proud that you can speak with an American accent? Why?

- Yes

- Sometimes

- No

- Why?

7) Would you still speak with an American accent if you were talking with the 
following people?

- Your teachers at The English Department

- Your classmates at The English Department

- Friends

- Family

- Cousins

8) While speaking English, what is more important to you?

- Good pronunciation (e.g. using "p" correctly instead of saying "b")

- Correct grammar

- Perfect American accent

- To be understood by the person listening to you

- Other

9) Why do you choose to speak English with an American accent?

- To sound cool

- To sound smart

- To sound educated

- It is easier than British English

- American English is all around us

- Other

10) Number the following language skills, used when speaking English, in the order of importance to you: where 4 would be most important and 1 would be least important.

- Grammar

- Vocabulary

- Pronunciation

- Style

11) How long did it take you to become fluent at speaking American English?

- 1 year

- 2 years

- Gradually over the years

12) On a scale of 1 to 10 ( 1 being poor and 10 being perfect), how would you rate your language proficiency (abilities)?

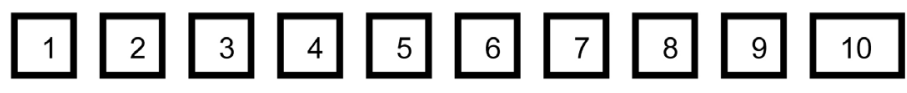

13) On a scale of 1 to 10 ( 1 being poor and 10 being perfect), how good do you think your American accent is?

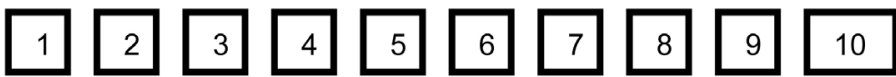

14) If you were to advice other people who want to learn to speak like you, what would you tell them? (Write in Arabic or English to express your point of view). 
Thank you! 